\title{
The integrated use of excreta-based vermicompost and inorganic NP fertilizer on tomato (Solanum lycopersicum L.) fruit yield, quality and soil fertility
}

\author{
Tesfu Mengistu ${ }^{1} \cdot$ Heluf Gebrekidan ${ }^{1} \cdot$ Kibebew Kibret $^{1} \cdot$ Kebede Woldetsadik $^{2} \cdot$ \\ Beneberu Shimelis ${ }^{1} \cdot$ Hiranmai Yadav $^{1}$
}

Received: 20 May 2016/ Accepted: 13 January 2017/Published online: 25 January 2017

(C) The Author(s) 2017. This article is published with open access at Springerlink.com

\begin{abstract}
Purpose A field study was conducted at Dire Dawa, Eastern Ethiopia, with an objective to find out an optimum combination of inorganic (NP) fertilizer and excreta-based vermicompost for best economic yield and quality of tomato and to assess their effect on selected physicochemical properties of amended soil after crop harvest.

Methods The experiment consisted of eight treatments where the mineral (NP) fertilizer and the excreta-based vermicompost were combined in different proportions being arranged in a completely randomized block design replicated three times.
\end{abstract}

Electronic supplementary material The online version of this article (doi:10.1007/s40093-017-0153-y) contains supplementary material, which is available to authorized users.

Tesfu Mengistu

tesfata.menge@gmail.com

Heluf Gebrekidan

helufg@gmail.com

Kibebew Kibret

kibebewkibrett@gmail.com

Kebede Woldetsadik

kwolde58@gmail.com

Beneberu Shimelis

beneberu.shimelis@gmail.com

Hiranmai Yadav

mayahiranbt@gmail.com

1 School of Natural Resources Management and Environmental Sciences, Haramaya University, P.O. Box 138, Dire Dawa, Ethiopia

2 School of Plant Sciences, Haramaya University, P.O. Box 138, Dire Dawa, Ethiopia
Results Growth, yield and quality attributes of tomato as well as the post-harvest soil nutrient status were markedly influenced by the nutrient treatments. The highest values for the various growth, yield and quality attributing parameters were recorded for the treatment combination consisting $75 \%$ of the recommended rate of NP fertilizer +11.25 ton $\mathrm{ha}^{-1}$ vermicompost (T6), this treatment was also observed to have the highest net benefit with acceptable economic return as well as a fairly high residual soil nutrient status. Following this treatment, is the integration of $50 \%$ of recommended rate of NP fertilizer +7.5 ton $\mathrm{ha}^{-1}$ vermicompost (T3) which surpassed the sole mineral fertilizer and vermicompost in terms of the crop's yield and its economic return.

Conclusion $25-50 \%$ of the recommended rate of chemical fertilizer can be supplemented through vermicompost. However, in order to generate more reliable information, there is a need to conduct more such studies using more integration ratios of these nutrient sources (NP fertilizer and vermicompost) at various soil and agro-climatic conditions.

Keywords Excreta $\cdot$ NP fertilizer $\cdot$ Quality $\cdot$ Soil physicochemical properties $\cdot$ Tomato $\cdot$ Yield $\cdot$ Vermicompost

$\begin{array}{ll}\text { Abbreviations } \\ \mathrm{NH}_{4} \mathrm{OAc} & \text { Ammonium acetate } \\ \text { ANOVA } & \text { Analysis of variance } \\ \mathrm{BD} & \text { Bulk density } \\ \mathrm{CEC} & \text { Cation exchange capacity } \\ \text { CIMMYT } & \text { International Maize and Wheat Improvement } \\ & \text { Center } \\ \text { DTPA } & \text { Di-ethylene tri-amine penta-acetic acid } \\ \text { EC } & \text { Electrical conductivity } \\ \text { ETB } & \text { Ethiopian birr }\end{array}$




$\begin{array}{ll}\text { FYM } & \text { Farm yard manure } \\ \text { LSD } & \text { Least significant difference } \\ \text { MC } & \text { Marginal costs } \\ \text { MNB } & \text { Marginal net benefits } \\ \text { MRR } & \text { Marginal rate of return } \\ \text { NB } & \text { Net benefits } \\ \text { OC } & \text { Organic carbon } \\ \text { OM } & \text { Organic matter } \\ \text { PBS } & \text { Percent base saturation } \\ \text { RDF } & \text { Recommended dose of fertilizer } \\ \text { NaOH } & \text { Sodium hydroxide } \\ \text { TA } & \text { Titratable acidity } \\ \text { TSS } & \text { Total soluble solids } \\ \text { TVC } & \text { Total variable cost } \\ \text { TSP } & \text { Triple super phosphate } \\ \text { USD } & \text { United States dollar }\end{array}$

\section{Background}

Increased productivity of cultivated land, reduced costs of production and higher input use efficiency with no harm to the soil, ground water, environment and product quality are the current development strategies of vegetable production (Singh et al. 2010). There is no doubt that chemical fertilizers are playing a vital role to meet the nutrient requirement of crops and thereby increase their production. However, in the present scenario the non-judicious use of fertilizers is posing both economic and ecological problems which are often difficult to face, particularly in developing countries (Sutton et al. 2011; Sun et al. 2012). Widespread nutrient deficiency in soils, disturbed soil reaction, development of nutrient imbalance in plant, increased susceptibility of plants to diseases, reduced soil organic matter, lesser occurrence of beneficial soil microorganism and increased environmental pollution as well as human health hazards are the key problems associated with indiscriminate and over use of synthetic fertilizers (Das et al. 2015). The poor soil respiration rate and complete vanishing of natural decomposer communities from agro-ecosystems further threatens land sustainability and food security around the world (Suthar 2009).

Besides the ecological concerns, the rising cost of chemical fertilizers coupled with the low affordability to small holder farmers have led to growing interests among the scientific and farming community to shift their attention from chemical alone agriculture to integrated nutrient management strategy which utilizes both organic and inorganic nutrient forms (Singh et al. 2010). Since the nutrient turnover in soil plant system is considerably high in intensive farming, neither the chemical fertilizers nor the organic and biological sources alone can achieve production sustainability (Javaria and Khan 2011). Sole application of organic sources cannot maintain and synchronize the required nutrient supply to the growing plant due to lesser quantity of mineral nutrients or time needed for their mineralization to release nutrients for plant uptake (Akhtar et al. 2011). Likewise, chemical fertilizers, even with balanced use, could not maintain high yield level over the years because of deterioration in soil physical and biological environments due to low organic matter content in soils (Javaria and Khan 2011). Thus, the integrated use of the organic and inorganic nutrient sources has assumed great significance in recent years (Prativa and Bhattarai 2011). In addition to supply of nutrients, organic sources improve the physical condition and biological health of soil, which improves the availability of applied and native nutrients (Dick and Gregorich 2004). Integrating chemical fertilizer along with composted organic materials could be more effective, economical and sustainable for both agriculture and environment (Reddy and Reddy 2011; Koushal et al. 2011).

Nevertheless, in Ethiopia, large-scale availability of organic materials from traditional sources such as crop residues and animal manures is becoming a series challenge, because these sources of organic materials are under competing uses for livestock feed, fuel, thatching, temporary construction and others (IFPRI 2010). This scenario would, therefore, dictate the farming community to look for and effectively utilize alternative off-farm organic sources of soil ameliorants. In this regard, it is interesting that quite huge amount of solid wastes are generated from municipalities, a large part of which is organic and biodegradable. In addition to the municipal solid wastes, the human excreta also constitute a significant component of wastes generated from cities. Such urban wastes consist of nutrients and organic matter that can be recycled for agriculture in and around cities where the challenge of urban food security has facilitated the development of urban and peri-urban agriculture (Cofie and Adamtey 2009).

A considerable quantity of municipal solid organic wastes and dried faecal sludge are generated from Dire Dawa city. Unfortunately, as there is no effort to recycle these wastes for agriculture, the wastes are simply disposed at the landfill site, which would, otherwise been used to fertilize and ameliorate the predominantly sandy soils of the region that naturally have low fertility and organic matter content and thereby promote sustainable urban and peri-urban agriculture and enhance productivity. However, the safe use of wastes involving faecal matter as organic fertilizer is highly, if not absolutely, dependent on the effective treatment of faecal sludge. Untreated faecal matter contains several pathogens that pose health threats to human life. Therefore, in order to obtain faecal compost that is safe for agricultural use, the pathogenic organisms 
must be eliminated (Agyekum 2015). In this regard, combining thermophilic composting and vermicomposting has recently been considered as an effective means of achieving stabilized and hygienic product (Mupondi et al. 2010). The end product (vermicompost) that results from the interactions between earthworms and microorganisms during the breakdown of organic matter is a nutrient-rich and microbiologically active organic amendment (Domínguez 2004). Moreover, being a rich source of macro- and micro-nutrients, vitamins, plant growth regulators and beneficial microbes, vermicompost appears to be the best organic source in maintaining soil fertility on sustainable basis towards an eco-friendly environment (Edwards and Arancon 2004).

It has been reported that vermicompost application to different crop reduces the requirement of chemical fertilizer without any reduction in crop yield (Giraddi 2000). Thus, with a view to reduce the cost and indiscriminate use of chemical fertilizers that may result in losses of fertilizer elements leading to deterioration of soil health and environment as well as decline in production and productivity of various crops, substituting part of the chemical fertilizers by such locally available organic sources of nutrients is vital (Koushal et al. 2011; Saraswathy and Prabhakaran 2014). Although good amount of research work has been done to study the effect of vermicompost on different vegetable crops, local efforts made so far, to determine the extent of reduction of inorganic fertilizers by applying vermicompost as an organic source for tomato production are very limited. Therefore, there is a need to elucidate the appropriate combinations of these nutrient sources to obtain financially viable yield of the crop. Concomitantly, keeping in view the quantum of municipal solid waste and excreta generation of Dire Dawa city and their potential use for promoting urban vegetable production through vermicomposting, the present study is aimed at the identification of a suitable integration ratio of vermicompost from human wastes and chemical fertilizers for the most economic output of tomato production - one of the commonly grown vegetable crop in the study area.

\section{Material and methods}

\section{Description of the study area}

The field experiment was conducted at Dire Dawa which is located at $9^{\circ} 6^{\prime} \mathrm{N}, 41^{\circ} 8^{\prime} \mathrm{E}$ and at an altitude of $1197 \mathrm{~m}$ above sea level in Eastern Ethiopia. The site lies in the semi-arid belt of the eastern rift valley escarpment. The monthly mean maximum and minimum temperature of the area ranges from $28.8{ }^{\circ} \mathrm{C}$ in December and January to $35.0{ }^{\circ} \mathrm{C}$ in June and from $14.9^{\circ} \mathrm{C}$ in December to $22.7^{\circ} \mathrm{C}$ in June,
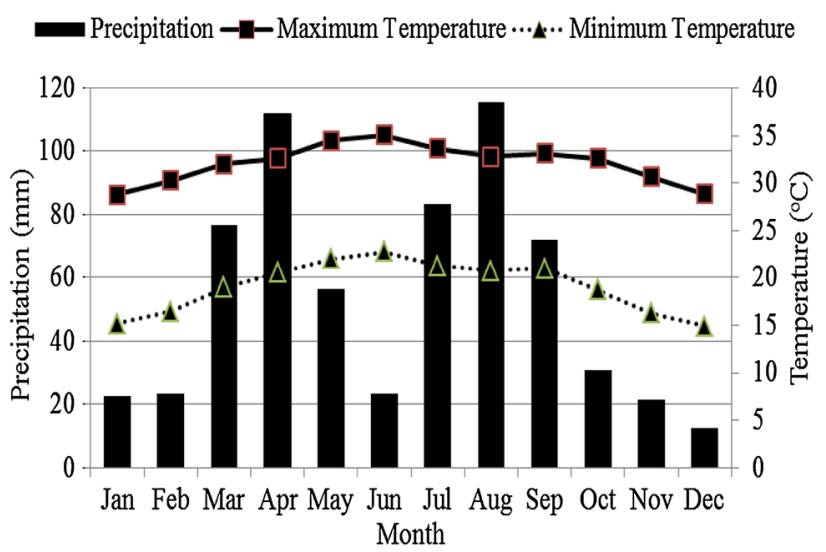

Fig. 1 Monthly average precipitation, maximum and minimum temperatures of the experimental area recorded during (1980-2013). Source: National Meteorology Agency

respectively. The area enjoys a bi-modal type of rainfall that extends from March to May and July to September for the small and main rainy seasons, respectively. The aggregate average annual rainfall that the area gets from these two seasons is about $515.64 \mathrm{~mm}$ (Fig. 1). The present experiment was undertaken during the drier season from October to February 2013/2014 using irrigation.

\section{Characterization of vermicompost}

The vermicompost used in this experiment was made from municipal solid organic wastes (collected from various locations of Dire Dawa city) and dried faecal sludge (obtained from the city's faecal sludge dewatering and drying bed) in 2:1 ratio. The waste mixture was first thermocomposted for 15 days in windrows and then vermicomposted using earthworms (Eisenia foetida) for about 85 days. Analysis for $\mathrm{pH}$ and electrical conductivity (EC) of the vermicompost were performed in extracts of 1:10 (w/v) compost:distilled water ratio as described by Ndegwa and Thompson (2001). Total $\mathrm{N}$ was measured by the Kjeldahl method. Total organic carbon (C) was determined by the Walkley and Black method (Walkley and Black 1934). Total $\mathrm{P}, \mathrm{Ca}, \mathrm{Mg}, \mathrm{K}, \mathrm{Fe}, \mathrm{Mn}, \mathrm{Cu}$ and $\mathrm{Zn}$ were extracted following the wet digestion method (Okalebo et al. 2002). The concentration of $P$ was determined by the molybdenum blue colouration method. Total cations $(\mathrm{Ca}$ and $\mathrm{Mg}$ ) and micronutrients $(\mathrm{Fe}, \mathrm{Mn}, \mathrm{Cu}$ and $\mathrm{Zn}$ ) were determined from the wet digested samples by atomic absorption spectrophotometer, while total $\mathrm{K}$ was estimated by flame photometer (Okalebo et al. 2002). The determination of total sulphur was carried out by total digestion of the vermicompost in di-acid mixture $\left(\mathrm{HClO}_{4}: \mathrm{HNO}_{3}\right)$ and the $\mathrm{S}$ concentration in the digests was measured by a turbidimetric procedure using barium chloride (Motsara and 
Table 1 Mean \pm SE values for selected physico-chemical properties of the experimental soil before planting and vermicompost

\begin{tabular}{|c|c|c|}
\hline \multirow[t]{2}{*}{ Properties } & \multicolumn{2}{|c|}{ Value (mean $\pm \mathrm{SE}$ ) } \\
\hline & Soil & Vermicompost \\
\hline Total $\mathrm{N}\left(\mathrm{g} \mathrm{kg}^{-1}\right)$ & $1.13 \pm 0.04$ & $14.75 \pm 0.4$ \\
\hline Available P $\left(\mathrm{mg} \mathrm{kg}^{-1}\right)$ & $21.22 \pm 0.25$ & - \\
\hline Total $\mathrm{P}\left(\mathrm{g} \mathrm{kg}^{-1}\right)$ & - & $7.45 \pm 0.57$ \\
\hline Organic carbon $\left(\mathrm{g} \mathrm{kg}^{-1}\right)$ & $11.53 \pm 0.19$ & $136.63 \pm 1.33$ \\
\hline $\mathrm{pH}$ & $8.56 \pm 0.01$ & $7.480 \pm 0.03$ \\
\hline $\mathrm{EC}\left(\mu \mathrm{s} \mathrm{cm}{ }^{-1}\right)$ & $461.33 \pm 0.88$ & $717.67 \pm 15.07$ \\
\hline Exchangeable $\mathrm{Ca}\left(\mathrm{Cmol}_{(+)} \mathrm{kg}^{-1}\right.$ soil $)$ & $13.31 \pm 0.26$ & $42.70 \pm 2.58^{\mathrm{a}}$ \\
\hline Exchangeable $\mathrm{Mg}\left(\mathrm{Cmol}_{(+)} \mathrm{kg}^{-1}\right.$ soil $)$ & $3.02 \pm 0.05$ & $6.56 \pm 0.08^{\mathrm{a}}$ \\
\hline Exchangeable $\mathrm{K}\left(\mathrm{Cmol}_{(+)} \mathrm{kg}^{-1}\right.$ soil $)$ & $0.80 \pm 0.04$ & $3.42 \pm 0.28^{\mathrm{a}}$ \\
\hline Exchangeable $\mathrm{Na}\left(\mathrm{Cmol}_{(+)} \mathrm{kg}^{-1}\right.$ soil $)$ & $0.58 \pm 0.03$ & $1.21 \pm 0.17^{\mathrm{a}}$ \\
\hline Cation exchange capacity $(\mathrm{CEC})\left(\mathrm{Cmol}_{(+)} \mathrm{kg}^{-1}\right.$ soil) & $20.30 \pm 0.31$ & - \\
\hline Percent base saturation (PBS) $(\%)$ & $87.30 \pm 1.44$ & - \\
\hline $\mathrm{Fe}\left(\mathrm{mg} \mathrm{kg}^{-1}\right)(\mathrm{DTPA})$ & $7.14 \pm 0.29$ & $7.21 \pm 0.07^{\mathrm{a}}$ \\
\hline $\operatorname{Mn}\left(\mathrm{mg} \mathrm{kg}^{-1}\right)(\mathrm{DTPA})$ & $17.12 \pm 0.12$ & $355.95 \pm 10.69^{b}$ \\
\hline $\mathrm{Zn}\left(\mathrm{mg} \mathrm{kg}^{-1}\right)$ (DTPA) & $4.12 \pm 0.04$ & $331.32 \pm 12.98^{\mathrm{b}}$ \\
\hline $\mathrm{Cu}\left(\mathrm{mg} \mathrm{kg}^{-1}\right)$ (DTPA) & $2.11 \pm 0.03$ & $37.17 \pm 1.33^{\mathrm{b}}$ \\
\hline Sand $(\%)$ & $49.67 \pm 1.45$ & - \\
\hline Silt $(\%)$ & $22.33 \pm 0.88$ & - \\
\hline Clay $(\%)$ & $28.00 \pm 0.58$ & - \\
\hline Bulk density $\left(\mathrm{g} \mathrm{cm}^{-3}\right)$ & $1.41 \pm 0.05$ & - \\
\hline Moisture $\left(\mathrm{g} \mathrm{kg}^{-1}\right)$ & - & $377.49 \pm 2.47$ \\
\hline
\end{tabular}

a Total $\left(\mathrm{Ca}, \mathrm{Mg}, \mathrm{K}, \mathrm{Na}, \mathrm{Fe}\right.$ in $\left.\mathrm{g} \mathrm{kg}^{-1}\right)$

b Total (Mn, $\mathrm{Zn}, \mathrm{Cu}$ in $\mathrm{mg} \mathrm{kg}^{-1}$ )
Roy 2008). The laboratory analytical results revealed that the vermicompost contained reasonable quantities of the essential macro- and micro-nutrients (Table 1). Additional data on the chemical composition of the municipal solid organic waste and dried faecal sludge are given in Additional file 1 .

\section{Characterization of soil}

The initial surface soil samples were collected prior to the layout of the treatments to assess the selected physicochemical characteristics of the soil. Soil samples were also drawn after harvesting of the crop for studying the postharvest soil characteristics. Determination of particle size distribution (texture) was carried out following the Boyoucous hydrometer method (Day 1965). Bulk density was estimated from undisturbed soil samples following the core sampling method (Sahlemedhin and Taye 2000). Total porosity was estimated from the values of bulk density and particle density (The average soil particle density value of $2.65 \mathrm{~g} \mathrm{~cm}^{-3}$ for mineral soils was assumed). Soil $\mathrm{pH}$ (McLean 1982) and electrical conductivity (Rhoades 1982) were determined from a suspension of 1:2.5 of soil:water ratio using glass electrode attached to a digital $\mathrm{pH}$ meter and EC meter, respectively. The Exchangeable bases $(\mathrm{Ca}$, $\mathrm{Mg}, \mathrm{K}$, and $\mathrm{Na}$ ) and cation exchange capacity (CEC) were determined by leaching method with ammonium acetate solution (1 $\left.\mathrm{M} \mathrm{NH}_{4} \mathrm{OAc}\right)$. The concentration of exchangeable $\mathrm{Ca}$ and $\mathrm{Mg}$ were measured from the extract with atomic absorption spectrophotometer while exchangeable $\mathrm{K}$ and $\mathrm{Na}$ with flame photometer (Van Reeuwijk 2002). Percent base saturation (PBS) was calculated from the sum of exchangeable bases as a per cent of the CEC of the soil. The organic carbon (OC) was determined by dichromate oxidation method and subsequent titration with ferrous ammonium sulphate (Walkley and Black 1934) and \% organic matter (OM) was obtained by multiplying \% OC by 1.724 assuming that average $\mathrm{C}$ concentration of organic matter is $58 \%$. The total soil nitrogen was estimated using the Kjeldahl procedure. The determination of available phosphorous was carried out following the Olsen extraction method (Olsen et al. 1954). Available micronutrients (Fe, $\mathrm{Mn}, \mathrm{Zn}$ and $\mathrm{Cu}$ ) were extracted with di-ethylene tri-amine penta-acetic acid (DTPA) as described by Lindsay and Norvell (1978) and their amounts in the extracts were determined by atomic absorption spectrophotometer. The 
selected physico-chemical properties of the initial soil (before planting) is presented in Table 1.

\section{Treatments and experimental design}

A tomato variety commonly grown in the area (Roma VF) was used for the study. Tomato seedlings were raised in a glasshouse and at $15 \mathrm{~cm}$ height (about 25 days after sowing) the seedlings were transplanted to the experimental field. Planting was done by adopting the recommended spacing of $75 \mathrm{~cm}$ between rows and $50 \mathrm{~cm}$ between plants. Each experimental plot had a gross area of $15 \mathrm{~m}^{2}$ with $5 \mathrm{~m}$ length and $3 \mathrm{~m}$ width. A distance of 1.5 and $2 \mathrm{~m}$ was maintained between plots in each replication and between blocks, respectively. All other agronomic practices (weeding, cultivation, furrow irrigation, etc.) were employed for each plot as per the recommendations.

The experiment consisted of eight treatments including a control which were defined according to the different levels of inorganic (NP) fertilizers and vermicompost. The treatment details are given below (Table 2). The recommended dose of $\mathrm{N}$ and $\mathrm{P}$ for tomato (Roma VF) is 105 and $40 \mathrm{~kg} \mathrm{ha}^{-1}$, respectively (EARO 2004). However, the pre planting soil test for $\mathrm{P}$ of the experimental soil being relatively higher, an adjustment was made to the amount of $\mathrm{P}$ fertilizer added to $60 \%$ as suggested by Srinivasan (2010). Urea and triple super phosphate (TSP) were used as a source of $\mathrm{N}$ and $\mathrm{P}$, respectively. 15 ton ha ${ }^{-1}$ of vermicompost was considered as a full dose for tomato (Singh et al. 2010).

The treatments were arranged in a randomized complete block design with three replications. The full dose of $\mathrm{P}$ and half dose of $\mathrm{N}$ fertilizer were applied at transplanting and the remaining half dose of $\mathrm{N}$ was side-dressed two weeks after transplanting (EARO 2004). The vermicompost was incorporated into the soil a week before transplanting the seedlings as per the treatments.

Table 2 Description of the fertilizer treatments

\begin{tabular}{ll}
\hline Treatment code & Description \\
\hline $\mathrm{T} 1$ & $0 \% \mathrm{RDF}+0$ ton $\mathrm{ha}^{-1}$ vermicompost (control) \\
$\mathrm{T} 2$ & $25 \% \mathrm{RDF}+3.75 \mathrm{ton} \mathrm{ha}^{-1}$ vermicompost \\
$\mathrm{T} 3$ & $50 \% \mathrm{RDF}+7.5 \mathrm{ton} \mathrm{ha}^{-1}$ vermicompost \\
$\mathrm{T} 4$ & $75 \% \mathrm{RDF}+3.75 \mathrm{ton} \mathrm{ha}^{-1}$ vermicompost \\
$\mathrm{T} 5$ & $25 \% \mathrm{RDF}+11.25 \mathrm{ton} \mathrm{ha}^{-1}$ vermicompost \\
$\mathrm{T} 6$ & $75 \% \mathrm{RDF}+11.25 \mathrm{ton} \mathrm{ha}^{-1}$ vermicompost \\
$\mathrm{T} 7$ & $100 \% \mathrm{RDF}+0$ ton $\mathrm{ha}^{-1}$ vermicompost \\
$\mathrm{T} 8$ & $0 \% \mathrm{RDF}+15$ ton ha $\mathrm{ha}^{-1}$ vermicompost \\
\hline
\end{tabular}

$R D F$ recommended dose of fertilizer

\section{Data collection}

Agronomic data

Measurements on plant height, number of branches, number of fruit clusters per plant and number of fruits per cluster were taken from ten randomly sampled plants of the central rows of each experimental plot. The total number of marketable and unmarketable (cracked, damaged and infected) fruits per plant was obtained by counting the number of fruits of the respective categories from the successive harvests of pre-selected plants of each plot (dropped fruits were not considered at all).

Days to flowering and maturity were recorded when approximately 50 and $90 \%$ of the plant population in each plot, started flowering and attained their first crop harvest, respectively. During peak harvest of the crop, ten sample fruits were randomly taken from the central rows of each plot and the average fruit length $(\mathrm{mm})$, width (diameter) $(\mathrm{mm})$, weight $(\mathrm{g})$, volume $\left(\mathrm{cm}^{3}\right)$, and juice content $\left(\mathrm{ml} \mathrm{kg}^{-1}\right)$ were measured and recorded. For the determination of fruit dry matter, ten randomly taken fruits of each plot were sliced into pieces and a subsample of $200 \mathrm{~g}$ of sliced fruit was oven dried at $70{ }^{\circ} \mathrm{C}$ to a constant weight. The dried sample was re-weighted to calculate the percent dry weight. The total marketable and unmarketable fruits obtained from the successive harvests of the central rows of each plot were summed up to determine the final yield of each category on hectare basis (ton ha ${ }^{-1}$ ).

\section{Chemical analysis of tomato fruits}

An aliquot of juice was extracted from sampled fruits of each plot using a juice extractor and the slurry was filtered using cheesecloth. The clear juice was analysed for $\mathrm{pH}$, total soluble solids (TSS) and titratable acidity. The total soluble solids (TSS) of the fruits were determined on a portable hand refractometer standardized with distilled water and expressed in ${ }^{\circ}$ Brix (Waskar et al. 1999). $\mathrm{pH}$ was measured using a $\mathrm{pH}$ meter fitted with a glass electrode as described by Nunes and Emond (1999). The titratable acidity was obtained by titrating $10 \mathrm{~g}$ of tomato juice against $0.1 \mathrm{~N} \mathrm{NaOH}$ using phenolphthalein solution (1\%) as indicator and expressed as percentage of citric acid (Garner et al. 2008).

\section{Soil data}

Post-harvest soil samples were analysed for soil texture (particle size), bulk density, total porosity, pH, EC, CEC, exchangeable bases, PBS, organic carbon, total $\mathrm{N}$, available $\mathrm{P}$, and available micronutrients $(\mathrm{Fe}, \mathrm{Mn}, \mathrm{Zn}$ and $\mathrm{Cu}$ ) following the methods described earlier (2.3). 


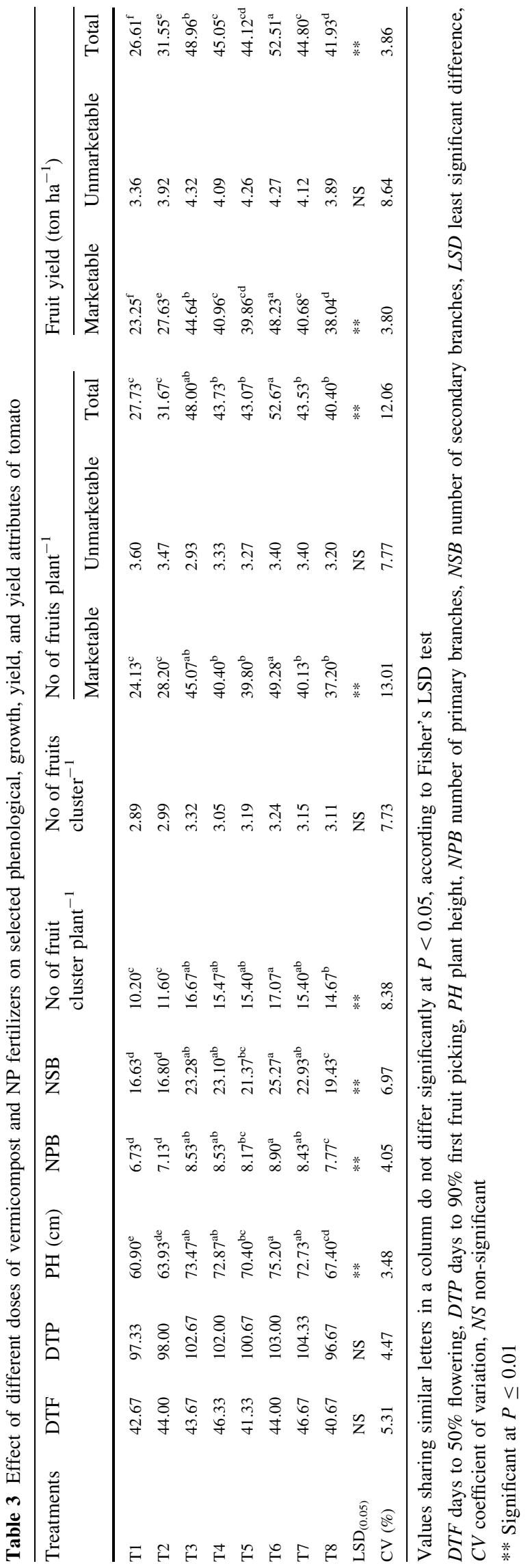

Economic analysis

Partial budget analysis involving marginal rate of return was calculated for the marketable yield to obtain the economically optimum combination of applied NP fertilizer and vermicompost. The prices of Urea, TSP and tomato fruit were valued based on the prices of the local market during the time of planting and harvesting which were considered to be $11.30,14.00$ and 5.00 ETB $\mathrm{kg}^{-1}$, respectively, $(1 \mathrm{ETB} \approx 0.05 \mathrm{USD})$. A wage rate of 25.0 Birr per man-day was assumed where ten and two mandays were considered for preparation and application of one ton of vermicompost, respectively. Gross field benefit (GFB), total variable cost (TVC) and net benefit (NB) were some of the concepts used in the partial budget analysis. The dominance analysis was also carried out to select potentially profitable treatments and a percentage marginal rate of return (\% MRR) was calculated for the non-dominated treatments (CIMMYT 1988).

\section{Data analysis}

All collected data were subjected to a one way analysis of variance to test for Least Significant Differences (LSD). Treatment means that are significantly different were compared using Fisher's LSD test at 5\% level. All analyses were performed using Statistics Analysis System (SAS version 9) software package. Economic analysis was carried out using CIMMYT's economic manual (CIMMYT 1988).

\section{Results and discussion}

\section{Effect of different doses of vermicompost and NP fertilizers on phenological and growth parameters}

Days to 50\% flowering and $90 \%$ first fruit harvest

The analysis of variance for days to $50 \%$ flowering and $90 \%$ first fruit picking revealed a non-significant difference $(P>0.05)$ among the treatments (Table 3). However, plots treated with high level of vermicompost with reduced mineral fertilizer were observed to have plants which flowered and matured earlier than those plants which received a higher mineral fertilizer and reduced vermicompost. Accordingly, plants that received sole vermicompost at a rate of 15 ton ha $\mathrm{h}^{-1}$ (T8) were found to flower and subsequently mature at least 6 and 7 days earlier to those treated with sole chemical fertilizer (T7). This corresponded to a 12.86 and $7.34 \%$ advancement of the former over the latter for flowering and first fruit picking, respectively. Some possible reasons for the relative 
earliness of tomato in vermicompost loaded treatments could be due to biological effects such as increases in beneficial enzymatic activities, increased population of beneficial microorganisms, or the presence of biologically active plant growth influencing substances such as plant growth regulators or plant hormones and humic acids in the vermicompost (Atiyeh et al. 2001, Singh et al. 2008; Nikbakht et al. 2008). Nath and Singh (2011) reported a reduction in flowering period of tomato in treatments that have received vermicompost of different animal and agro wastes.

\section{Plant height}

The results showed the significant effects of vermicompost, mineral fertilizer and mix treatments on plant height. Except for T2 which was statistically not different from the control (T1), all other treatments significantly $(P \leq 0.01)$ increased the plant height (Table 3 ). The highest plant height $(75.20 \mathrm{~cm})$ was noted in the treatment receiving $75 \%$ RDF along with 11.25 ton ha $^{-1}$ vermicompost (T6), while the lowest value $(60.89 \mathrm{~cm})$ was recorded for the control treatment (T1). The average height of plants grown receiving the former treatment (T6) exceeded those in the latter (T1) by about $23.5 \%$. However, significant differences did not exist among T3, T4, T6 and T7 treatments. The plant height resulted from the sole application of vermicompost at 15 ton $\mathrm{ha}^{-1}$ (T8) was statistically the same with T2 and T5 while it was significantly shorter than T3, T4, T6 and T7 (Table 3). These results were in agreement with the findings of Yourtchi et al. (2013) who reported the significant impact of combined use of vermicompost and chemical fertilizer on height of potato plant over the sole application of vermicompost. Chatterjee et al. (2014) also demonstrated maximum height in tomato plants when $25 \%$ of the RDF was supplemented with vermicompost and bio fertilizer.

\section{Number of branches}

Similar effects were also observed for number of primary and secondary branches. The treatment comprising $75 \%$ of RDF and 11.25 ton $\mathrm{ha}^{-1}$ vermicompost (T6) recorded the highest number of both primary and secondary branches (8.90 and 25.27) which were at par with T3, T4, and T7 treatments. The sole vermicompost treatment (T8), however, resulted in a significantly lower number of branches than the above treatments (Table 3). This is in accordance with the reports of Dass et al. (2008) and Chatterjee et al. (2014) who recorded maximum number of branches of tomato when 50 and $25 \%$ of the recommended rate of chemical fertilizers (NPK) was supplemented with 4 and 5 ton $\mathrm{ha}^{-1}$ vermicompost, respectively.
Besides supplying the essential nutrients, the positive effect of vermicompost on the growth of tomato might be related to the presence of plant growth regulators, humic acids, increased microbial diversity and activity and improvement of physical structure of the soil (Arancon et al. 2005; OlivaLlaven et al. 2008; Fernández-Luqueño et al. 2010; Singh et al. 2010). Thus, vermicompost might have an additive effect in enhancing the growth and development of the crop when integrated with the mineral fertilizer.

\section{Effect of different doses of vermicompost and NP fertilizers on yield and yield attributes of tomato}

Nutrient treatments exerted a significant influence on number of fruit cluster, number of marketable and total fruits per plant. The highest number of fruit cluster, marketable fruit and total fruit per plant was recorded for T6 followed by $\mathrm{T} 3$, both of which were surpassing treatments having sole $100 \%$ mineral fertilizer and vermicompost. However, the values of these variables for the latter treatment (T3) were in statistical parity with T4, T5, T7 and T8 (Table 3). Plants treated with $75 \%$ RDF along with 11.5 ton ha $^{-1}$ vermicompost (T6), recorded 67.35 and $89.94 \%$ more number of fruit cluster and total number of fruits per plant, respectively, over the control treatment. These findings were in agreement with the reports of Prativa and Bhattarai (2011) and Chatterjee et al. (2014) who noted maximum number of fruit clusters in treatments receiving $75 \%$ of RDF (NPK) combined with higher amount of organic manure including vermicompost. They considered the increased uptake of NPK due to the solubilization effect of plant nutrients by the addition of vermicompost and FYM. This reaffirms the significance of the integrated use of vermicompost and inorganic fertilizers in enhancing the performance of tomato over the individual nutrient sources. Regarding number of fruits per cluster and number of unmarketable fruits per plant, a non-significance difference $(P>0.05)$ was recorded among the treatments.

The marketable and total yield of tomato were markedly influenced by the application of NP fertilizer, vermicompost and their combination and they followed a similar trend as the marketable and total fruit number per plant. Integrating $75 \%$ RDF with 11.25 ton $\mathrm{ha}^{-1}$ of vermicompost (T6) gave the best marketable and total yield (48.23 and 52.51 ton $\mathrm{ha}^{-1}$ ) which was significantly different from other treatments investigated, followed by T3 (44.64 and 48.96 ton $\mathrm{ha}^{-1}$ ). The minimum yields (23.25 and 26.61 ton $\mathrm{ha}^{-1}$ ) of the respective variables were recorded for the control treatment (T1). T6 and T3, respectively, had a marketable yield advantage of 107.44 and $92 \%$ over the control, 18.68 and $9.73 \%$ over the sole mineral fertilizer (T7); and 26.79 and $17.35 \%$ over the sole vermicompost 
(T8) treatments. The total and marketable yield variations among $\mathrm{T} 4, \mathrm{~T} 5$ and $\mathrm{T} 7$ and between $\mathrm{T} 5$ and $\mathrm{T} 8$ were statistically not significant $(P>0.05)$. The results of the present study were in agreement with those obtained by Chatterjee et al. (2014) who reported a great increase in yield of tomato when $75 \%$ RDF chemical fertilizer was combined with higher amount of manure including vermicompost and bio fertilizer. The authors had also substantiated vermicompost as a better organic nutrient source over farmyard manure.

It is evident from the previous data that the highest values for the various growth and yield attributing parameters were recorded for T6. Thus, this treatment (T6) appeared to be the most favourable treatment combination compared to other integration ratios. The superiority of the treatment may be due to the fact that it might have taken advantage of the merits conferred by both vermicompost and chemical fertilizer in a most poised condition. As suggested by Srivastava et al. (2012), the integrated application of vermicompost and mineral fertilizer in appropriate ratio resulted in more balanced nutrient contents, microbial population and OM. This might have led to increased uptake of essential nutrients which in turn resulted in increased vegetative growth of the plant to help for better carbohydrate build up that subsequently contributed to higher fruit yield and quality components (Suge et al. 2011). Moreover, as Namazi et al. (2015) elaborated, adding vermicompost to the soil not only increased the nutritious elements needed for the plant but also improved the soil environment, encouraging the proliferation of roots to draw more water and nutrients from larger areas, finally resulting in improved biological function of the plant.

\section{Effect of different doses of vermicompost and NP fertilizer on fruit characteristics of tomato}

The mineral (NP) fertilizer and vermicompost, alone and in combination significantly increased fruit length and diameter $(P \leq 0.05)$; fruit volume, weight and dry matter $(P \leq 0.01)$ compared to the control treatment (Table 4). The highest fruit length $(64.97 \mathrm{~mm})$ and diameter $(42.93 \mathrm{~mm})$ was recorded for T6 and T3, respectively, however, both of these treatments were in statistical parity with each other and with T4, T5, T7 and T8 for both variables. The highest fruit volume and weight $\left(65.69 \mathrm{~cm}^{3}\right.$ and $62.81 \mathrm{~g}$ ) was still obtained at T6 treatment followed by $\mathrm{T} 3$ and T5, whereas the lowest values of the respective variables were recorded for the control (T1) treatment. As indicated in Table 4, the integrated application of $75 \%$ RDF with 11.25 ton ha $^{-1}$ vermicompost (T6) as well as $50 \%$ RDF with 7.5 ton $\mathrm{ha}^{-1}$ of vermicompost (T3) significantly increased fruit size than the sole vermicompost (T6) did. An interesting result was that, even though statistically they were the same $(P>0.05)$, the values for fruit size and weight of the integrated treatments (T3, T4, T5 and T6) were found to surpass the sole treatments ( $\mathrm{T} 7$ and T8). The increased fruit size under integrated use of vermicompost and inorganic fertilizer may be due to large and balanced uptake of nutrients and effective utilization of these nutrients for increased synthesis of photo-assimilate (carbohydrates) which would later be partitioned and remobilized from the source to sink (from leaf towards developing fruits) (Chatterjee 2013).

Likewise, the nutrient treatments significantly $(P \leq 0.01)$ affected the fruit dry matter of tomato. The highest and lowest mean fruit dry matter content was

Table 4 Effect of different doses of vermicompost and NP fertilizers on size and selected quality parameters of tomato fruit

\begin{tabular}{|c|c|c|c|c|c|c|c|c|c|}
\hline Treatments & $\begin{array}{l}\text { Fruit diameter } \\
(\mathrm{mm})\end{array}$ & $\begin{array}{l}\text { Fruit length } \\
(\mathrm{mm})\end{array}$ & $\begin{array}{l}\text { Fruit weight } \\
(\mathrm{g})\end{array}$ & $\begin{array}{l}\text { Fruit volume } \\
\left(\mathrm{cm}^{3}\right)\end{array}$ & $\begin{array}{l}\text { Fruit dry matter } \\
(\%)\end{array}$ & $\begin{array}{l}\text { TSS }\left(^{\circ}\right. \\
\text { Brix) }\end{array}$ & $\begin{array}{l}\text { TA } \\
(\%)\end{array}$ & $\mathrm{pH}$ & $\begin{array}{l}\text { JV } \\
\left(\mathrm{ml} \mathrm{kg}^{-1}\right)\end{array}$ \\
\hline $\mathrm{T} 1$ & $39.44^{\mathrm{c}}$ & $59.83^{c}$ & $49.18^{\mathrm{c}}$ & $51.52^{\mathrm{c}}$ & $5.46^{\mathrm{c}}$ & $4.611^{\mathrm{d}}$ & 0.423 & 4.258 & 680.30 \\
\hline $\mathrm{T} 2$ & $40.11^{\mathrm{bc}}$ & $61.09^{\mathrm{bc}}$ & $50.65^{\mathrm{c}}$ & $53.02^{\mathrm{c}}$ & $5.54^{\mathrm{c}}$ & $4.656^{\mathrm{cd}}$ & 0.426 & 4.257 & 706.54 \\
\hline T3 & $42.93^{\mathrm{a}}$ & $64.83^{\mathrm{a}}$ & $61.42^{\mathrm{ab}}$ & $64.21^{\mathrm{ab}}$ & $6.14^{\mathrm{ab}}$ & $4.800^{\mathrm{ab}}$ & 0.415 & 4.244 & 703.48 \\
\hline $\mathrm{T} 4$ & $41.58^{\mathrm{ab}}$ & $63.54^{\mathrm{ab}}$ & $58.47^{\mathrm{ab}}$ & $61.21^{\mathrm{ab}}$ & $6.07^{\mathrm{ab}}$ & $4.744^{\mathrm{bc}}$ & 0.417 & 4.247 & 685.89 \\
\hline T5 & $41.72^{\mathrm{ab}}$ & $63.69^{\mathrm{ab}}$ & $59.91^{\mathrm{ab}}$ & $62.50^{\mathrm{ab}}$ & $5.89^{\mathrm{b}}$ & $4.811^{\mathrm{ab}}$ & 0.415 & 4.241 & 765.52 \\
\hline T6 & $42.87^{\mathrm{a}}$ & $64.97^{\mathrm{a}}$ & $62.81^{\mathrm{a}}$ & $65.68^{\mathrm{a}}$ & $6.25^{\mathrm{a}}$ & $4.889^{\mathrm{a}}$ & 0.418 & 4.233 & 739.62 \\
\hline $\mathrm{T} 7$ & $41.55^{\mathrm{ab}}$ & $63.36^{\mathrm{ab}}$ & $58.37^{\mathrm{ab}}$ & $61.10^{\mathrm{ab}}$ & $5.95^{\mathrm{b}}$ & $4.744^{\mathrm{bc}}$ & 0.417 & 4.250 & 753.74 \\
\hline $\mathrm{T} 8$ & $41.22^{\mathrm{ab}}$ & $63.01^{\mathrm{ab}}$ & $57.06^{\mathrm{b}}$ & $59.60^{\mathrm{b}}$ & $5.93^{\mathrm{b}}$ & $4.856^{\mathrm{ab}}$ & 0.413 & 4.233 & 695.71 \\
\hline $\operatorname{LSD}_{(0.05)}$ & $*$ & $*$ & ** & $* *$ & $* *$ & $* *$ & NS & NS & NS \\
\hline $\mathrm{CV}(\%)$ & 2.40 & 2.77 & 4.90 & 4.82 & 2.50 & 1.59 & 2.12 & 0.24 & 11.90 \\
\hline
\end{tabular}

Values sharing similar letters in a column do not differ significantly at $P<0.05$, according to Fisher's LSD test

TSS total soluble solids, TA titratable acidity, $J V$ juice volume, $L S D$ least significant difference, $C V$ coefficient of variation

* and ** significant at $P \leq 0.05$ and $P \leq 0.01$, respectively 
recorded for T6 and the control (T1) treatments, respectively. T6 was in statistical parity with $\mathrm{T} 3$ and $\mathrm{T} 4$ and the latter treatments (T3 and T4) were also statistically identical with $\mathrm{T} 5, \mathrm{~T} 7$ and $\mathrm{T} 8$. The mean fruit dry matter produced by plants treated with $75 \% \mathrm{RDF}+11.25$ ton $\mathrm{ha}^{-1}$ of vermicompost(T6) and $50 \% \mathrm{RDF}+7.5$ ton ha $\mathrm{ha}^{-1}$ of vermicompost (T3) exceeded the control treatment by about 14.47 and $12.45 \%$, respectively. The superiority of the integrated application of nutrients may be due to the positive response of organic and inorganic sources of nutrients combination in increasing the translocation and accumulation of photosynthetes in the plants (Singh et al. 2010). Moreover, the efficacy of vermicompost is supposed to be enhanced due to certain hormonal activity associated with it. All these might have resulted in the vigorous vegetative growth of the plant which in turn leads to increased partition of the photo-assimilates to the fruits and thereby increase the dry matter accumulation in the fruits.

\section{Effect of different doses of vermicompost and NP fertilizer on quality of tomato fruit}

A significant response to the nutrient treatment was observed for total soluble solid (TSS) of tomato fruit juice. TSS was significantly higher for T6 which is in statistical parity with T3, T5 and T8. The least value was recorded for the control treatment. The variation among treatments $\mathrm{T} 3$, $\mathrm{T} 4, \mathrm{~T} 5, \mathrm{~T} 7$, and $\mathrm{T} 8$ and between $\mathrm{T} 2, \mathrm{~T} 4$ and $\mathrm{T} 7$ were not significant $(P>0.05)$ (Table 4). Even though both the vermicompost and chemical fertilizer were responsible for the increased level of TSS, the contribution of vermicompost seems to be more pronounced than the mineral fertilizer. Fruits receiving sole chemical fertilizer recorded relatively lower values for TSS than the sole vermicompost and other combined treatments. In line with these findings, Chatterjee et al. (2013) reported enhanced fruit quality attributes; particularly total solids and vitamin content in plants receiving higher amounts of organic manure and reduced levels of inorganic nitrogen. The results are further substantiated by Toor et al. (2006) who demonstrated a significantly higher TSS for fruits harvested from plants that received compost than those harvested from the mineral fertilized plots.

The results for the analysis of variance revealed that, the variation in $\mathrm{pH}$, titratable acidity (\%TA) and juice volume $(\mathrm{JV})$ among the treatments was not significant $(P>0.05)$ (Table 4). These findings get support from Azarmi et al. (2008) and Chatterjee et al. (2013) who reported a nonsignificant effect of nutrient treatments on the $\mathrm{pH}$ and TA of tomato juice. Edossa et al. (2014) also disclosed the insignificant effect of mineral fertilizers (NP) on juice volume of tomato fruit.

\section{Economic analysis}

The partial budget analysis (Table 5) indicated that except for two treatments (T4 and T7) all other treatments (T1, T2, T3, T5, T6 and T8) were found to be non-dominated and thus, selected for the analysis of marginal rate of return (MRR). As indicated in Table 5, the highest net benefit $\left(210,181.1\right.$ Ethiopian birr (ETB) $\mathrm{ha}^{-1}$ ) was recorded for application of $75 \% \mathrm{RDF}+11.25$ tone $\mathrm{ha}^{-1}$ of vermicompost (T6) followed by application of half the recommended rate of NP fertilizer and 7.5 tone $\mathrm{ha}^{-1}$ vermicompost (T3) $\left(196,289 \mathrm{ETB} \mathrm{ha}^{-1}\right)$. However, the highest marginal rate of return (Table 6) was recorded for the latter treatment (T3) $(63,782.42 \%)$ followed by T5 $(24,296.1 \%)$ and sole application of 15 ton $\mathrm{ha}^{-1}$ vermicompost (T8) (2013.47\%). This indicates that, for every 1 Birr ha ${ }^{-1}$ invested on the respective treatments, there was a rate of return of $637.82 \mathrm{Birr} \mathrm{ha}^{-1}, 242.96 \mathrm{Birr} \mathrm{ha}^{-1}$ and 20.13 Birr ha ${ }^{-1}$. Nonetheless, as per CIMMYT (1988), all the non-dominated treatments resulted in a rate of return above the minimum acceptable value $(50-100 \%)$, therefore the treatment comprising $75 \%$ RDF plus 11.25 ton $\mathrm{ha}^{-1}$ vermicompost (T6) was found to provide the highest net benefit compared to other nutrient integration ratios tested in this study and its MRR is well above the minimum acceptable limit (50-100\%). Thus, this treatment can be regarded as relatively the best treatment in terms of its economic return.

\section{Effect of different doses of vermicompost and NP fertilizer on selected physico-chemical properties of the soil}

\section{$O M, p H$ and $E C$}

The organic matter content in the post-harvest soils was observed to increase linearly with vermicompost rate regardless of the chemical fertilizers; however a statistically significant increment was noticed only in those plots to which vermicompost was added at a rate of $\geq 7.5$ ton $\mathrm{ha}^{-1}$ (T3, T5, T6, and T8) (Table 7). Plots treated with vermicompost at a rate of 15 ton $\mathrm{ha}^{-1}$ (T8) scored the highest soil OM $(2.66 \%)$ which showed a $24.72 \%$ more OM content than the control treatment. The significant effect of vermicompost application on soil organic matter was also reported in other studies (Azarmi et al. 2008; Uz and Tavali 2014).Considering the soil $\mathrm{pH}$ and EC, the response of the plots to the added vermicompost and mineral fertilizer was statistically not significant $(P>0.05)$ (Table 7). Similar results were also reported by Uz and Tavali (2014). 


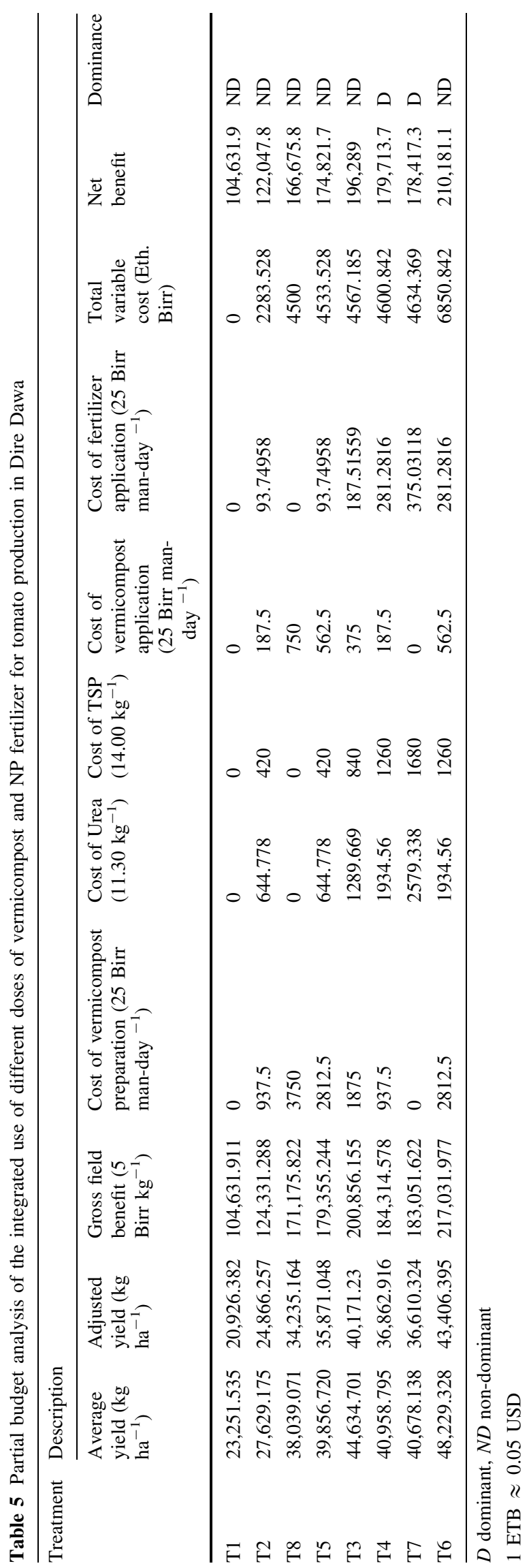

Exchangeable bases, CEC and PBS

The results for the analysis of variance indicated that regardless of the mineral fertilizer the values for exchangeable bases increased linearly with increased rate of vermicompost application. However, a statistically significant variation $(P \leq 0.01)$ among the treatments was observed only for Exchangeable $\mathrm{Ca}$ and $\mathrm{Mg}$ and not for $\mathrm{Na}$ and $\mathrm{K}$ (Table 7). The highest values for all the exchangeable bases were recorded for those plots treated with vermicompost at a rate of 15 ton $\mathrm{ha}^{-1}$ (T8), while plots that did not receive vermicompost at any rate have shown the lowest value. Both exchangeable $\mathrm{Ca}$ and $\mathrm{Mg}$ responded significantly to the added vermicompost when the vermicompost was applied at a rate of $\geq 7.5$ ton $\mathrm{ha}^{-1}$. The increase in these exchangeable bases to the added vermicompost may be due to the greater availability of these cations and the increased cation exchange capacity (CEC) resulted from the added vermicompost. The High cation exchange capacity (CEC) of humified organic matter is well documented, thus the application of vermicompost might have helped to increase the CEC of the soil and thereby to retain more of the cations in exchange sites. The findings of this study were in agreement with the reports of Nada et al. (2011).

Similarly, the CEC showed the same trend, being increased significantly $(P \leq 0.01)$ with the increased rate of vermicompost application regardless of the combined mineral fertilizer. The soil treated with 15 ton ha ${ }^{-1}$ vermicompost (T8) showed the greatest value, while the lowest value was recorded in the untreated soil (control) (Table 7). Applying vermicompost at a rate of 15 ton $\mathrm{ha}^{-1}$ was observed to increase the CEC by about $13.63 \%$ over the control treatment. The change in PBS among the treatments was, however, statistically not significant $(P>0.05)$, implying that the exchangeable bases and the corresponding CEC might have been changed proportionately.

\section{Bulk density and total porosity}

The soil bulk density and porosity tended to decrease and increase, respectively, with increased rate of vermicompost application (Table 7). However, the response of these properties of the soil to the added vermicompost was significant $(P \leq 0.05)$ only when the vermicompost was applied at a relatively higher rate ( $\geq 11.25$ ton/ha), even with such a rate there was a slight change of the respective parameters. Plots treated with 15 ton $\mathrm{ha}^{-1}$ of vermicompost were observed to have the lowest bulk density $\left(1.26 \mathrm{~g} \mathrm{~cm}^{-3}\right)$ and the highest porosity (52.52\%) which, respectively, had a $2.3 \%$ less and more of the respective measured variables over the control treatment. 
Table 6 The marginal rate of return for NP fertilizers and vermicompost in tomato production

\begin{tabular}{llllll}
\hline Treatment & TVC & MC & NB & MNB & MRR (\%) \\
\hline T1 & 0 & - & $104,631.9$ & - & 762.67 \\
T2 & 2283.528 & 2283.528 & $122,047.8$ & $17,415.85$ & 2013.47 \\
T8 & 4500 & 2216.472 & $166,675.8$ & $44,628.06$ & $24,296.10$ \\
T5 & 4533.528 & 33.52758 & $174,821.7$ & 8145.89 & $63,782.42$ \\
T3 & 4567.185 & 33.65701 & $196,289.0$ & $21,467.25$ & 1433.08 \\
T6 & 6850.842 & 2216.472 & $210,181.1$ & $31,763.88$ & \\
\hline
\end{tabular}

TVC total variable cost, $M C$ marginal costs, $N B$ net benefits, $M N B$ marginal net benefits, $M R R$ marginal rate of return

Table 7 Effect of different doses of NP fertilizer and vermicompost on selected physico-chemical properties of post-harvest soil

\begin{tabular}{|c|c|c|c|c|c|c|c|c|c|c|c|}
\hline \multirow[t]{2}{*}{ Treatments } & \multirow[t]{2}{*}{$\begin{array}{l}\mathrm{OM} \\
(\%)\end{array}$} & \multirow[t]{2}{*}{$\mathrm{pH}$} & \multirow[t]{2}{*}{$\begin{array}{l}\mathrm{EC} \\
\left(\mu \mathrm{scm}^{-1}\right)\end{array}$} & \multicolumn{4}{|c|}{$\begin{array}{l}\text { Exchangeable cations }\left(\mathrm{Cmol}_{(+)}\right. \\
\left.\mathrm{kg}^{-1}\right)\end{array}$} & \multirow[t]{2}{*}{$\begin{array}{l}\mathrm{CEC}\left(\mathrm{Cmol}_{(+)}\right. \\
\left.\mathrm{kg}^{-1}\right)\end{array}$} & \multirow[t]{2}{*}{$\begin{array}{l}\text { PBS } \\
(\%)\end{array}$} & \multirow[t]{2}{*}{$\begin{array}{l}\mathrm{BD} \\
\left(\mathrm{g} \mathrm{cm}^{-3}\right)\end{array}$} & \multirow[t]{2}{*}{$\begin{array}{l}\text { Porosity } \\
(\%)\end{array}$} \\
\hline & & & & $\mathrm{Ca}^{2+}$ & $\mathrm{Mg}^{2+}$ & $\mathrm{K}^{+}$ & $\mathrm{Na}^{+}$ & & & & \\
\hline $\mathrm{T} 1$ & $2.001^{\mathrm{d}}$ & 8.564 & 462.67 & $13.284^{\mathrm{d}}$ & $2.904^{\mathrm{c}}$ & 0.787 & 0.582 & $20.614^{\mathrm{e}}$ & 85.263 & $1.288^{\mathrm{a}}$ & $51.386^{\mathrm{c}}$ \\
\hline $\mathrm{T} 2$ & $2.129^{\mathrm{d}}$ & 8.578 & 464.44 & $14.133^{\mathrm{cd}}$ & $2.979^{\mathrm{bc}}$ & 0.803 & 0.728 & $21.239^{\mathrm{de}}$ & 87.808 & $1.278^{\mathrm{ab}}$ & $51.784^{\mathrm{bc}}$ \\
\hline $\mathrm{T} 3$ & $2.377^{\mathrm{bc}}$ & 8.573 & 472.78 & $14.817^{\mathrm{bc}}$ & $3.090^{\mathrm{ab}}$ & 0.820 & 0.728 & $22.176^{\mathrm{bcd}}$ & 87.727 & $1.273^{\mathrm{abc}}$ & $51.959^{\mathrm{abc}}$ \\
\hline $\mathrm{T} 4$ & $2.172^{\text {cd }}$ & 8.590 & 464.22 & $14.297^{\mathrm{bcd}}$ & $2.972^{\mathrm{bc}}$ & 0.820 & 0.698 & $21.551^{\mathrm{cde}}$ & 87.178 & $1.279^{\mathrm{abc}}$ & $51.720^{\mathrm{bc}}$ \\
\hline $\mathrm{T} 5$ & $2.507^{\mathrm{ab}}$ & 8.536 & 484.56 & $15.502^{\mathrm{ab}}$ & $3.158^{\mathrm{a}}$ & 0.820 & 0.669 & $22.800^{\mathrm{ab}}$ & 88.379 & $1.266^{\mathrm{bc}}$ & $52.245^{\mathrm{ab}}$ \\
\hline T6 & $2.412^{\mathrm{b}}$ & 8.562 & 483.22 & $15.420^{\mathrm{abc}}$ & $3.152^{\mathrm{a}}$ & 0.852 & 0.640 & $22.488^{\mathrm{abc}}$ & 89.226 & $1.248^{\mathrm{bc}}$ & $52.266^{\mathrm{ab}}$ \\
\hline $\mathrm{T} 7$ & $2.055^{\mathrm{d}}$ & 8.567 & 460.78 & $13.339^{\mathrm{d}}$ & $2.898^{\mathrm{c}}$ & 0.754 & 0.611 & $20.926^{\mathrm{e}}$ & 84.436 & $1.285^{\mathrm{a}}$ & $51.519^{c}$ \\
\hline $\mathrm{T} 8$ & $2.658^{\mathrm{a}}$ & 8.556 & 486.00 & $16.434^{\mathrm{a}}$ & $3.227^{\mathrm{a}}$ & 0.869 & 0.815 & $23.425^{\mathrm{a}}$ & 91.231 & $1.258^{\mathrm{c}}$ & $52.519^{\mathrm{a}}$ \\
\hline $\begin{array}{l}\text { LSD } \\
\qquad(0.05)\end{array}$ & $* *$ & NS & NS & $* *$ & $* *$ & NS & NS & $* *$ & NS & $*$ & $*$ \\
\hline $\mathrm{CV}$ & 5.61 & 0.73 & 3.28 & 5.24 & 3.22 & 9.61 & 23.88 & 3.15 & 3.88 & 0.78 & 0.72 \\
\hline
\end{tabular}

Values sharing similar letters in a column do not differ significantly at $P<0.05$, according to Fisher's LSD test

$O M$ organic matter, $E C$ electrical conductivity, $B D$ bulk density, $C E C$ cation exchange capacity, $P B S$ percent base saturation, $L S D$ least significant difference, $C V$ coefficient of variation, $N S$ non-significant

* and ** significant at $P \leq 0.05$ and $P \leq 0.01$, respectively

Although the improvements in soil bulk density and porosity following addition of vermicompost were not as such remarkable, there were indications that positive changes may be induced. As Smith et al. (1999) suggested repeated applications or applications of larger amounts of composted material may be required to produce significant improvements in the physical condition of the soil. Reduced bulk density and increased porosity of soils in response to added vermicompost has been reported in other studies (Ferreras et al. 2006; Azarmi et al. 2008; Gopinath et al. 2008).

\section{Selected macro- and micro-nutrients}

The results for the post-harvest soil analysis indicated significant $(P \leq 0.01)$ variations among the treatments for total $\mathrm{N}$ and available $\mathrm{P}$ (Table 8). Except for T2, all other treatments were observed to produce significantly higher $(P \leq 0.01)$ residual $\mathrm{N}$ in the soil as compared to the control plots (Table 8). The highest soil $\mathrm{N}$ was recorded on plots receiving $75 \% \mathrm{RDF}$ and 11.25 ton $^{-1}$ vermicompost (T6) which is in par with $\mathrm{T} 3, \mathrm{~T} 4, \mathrm{~T} 5$ and $\mathrm{T} 8$. It showed a $62.5 \%$ higher $\mathrm{N}$ over the control treatment (T1). Both the mineral $\mathrm{N}$ fertilizer and vermicompost might have contributed for the increased residual soil N. However, as indicated in Table 8, even though statistically they are the same, the residual soil $\mathrm{N}$ values of plots receiving sole mineral fertilizer is lower than those plots receiving integrated nutrition as well as sole vermicompost. This might be due to the loss of $\mathrm{N}$ through leaching in the former treatment, whereas in the latter cases, the vermicompost, by virtue of its increased nutrient retention capacity, might have reduced the nitrogen losses and thus, increase the availability of $\mathrm{N}$ in the soil to improve the fertilizer use efficiency (Prativa and Bhattarai 2011). There have been other reports of increase in residual soil $\mathrm{N}$ after application of vermicompost and mineral fertilizer (Azarmi et al. 2008; Sundararasu and Neelanarayanan 2012; Murmu et al. 2013). 
Table 8 Effect of different doses of NP fertilizer and vermicompost on total N, available P and micronutrients of post-harvest soil

\begin{tabular}{lllllll}
\hline Treatments & Total N $(\%)$ & Avail. P (ppm) & Avail. Fe (ppm) & Avail. Mn (ppm) & Avail. Zn (ppm) & Avail. Cu (ppm) \\
\hline T1 & $0.112^{\mathrm{c}}$ & $19.71^{\mathrm{d}}$ & $6.404^{\mathrm{c}}$ & $16.648^{\mathrm{c}}$ & $3.981^{\mathrm{c}}$ & 2.017 \\
T2 & $0.126^{\mathrm{c}}$ & $20.46^{\mathrm{cd}}$ & $6.833^{\mathrm{bc}}$ & $17.169^{\mathrm{c}}$ & $4.124^{\mathrm{c}}$ & 2.059 \\
T3 & $0.159^{\mathrm{ab}}$ & $24.33^{\mathrm{ab}}$ & $7.595^{\mathrm{ab}}$ & $17.718^{\mathrm{bc}}$ & $4.326^{\mathrm{bc}}$ & 2.123 \\
T4 & $0.163^{\mathrm{ab}}$ & $24.75^{\mathrm{ab}}$ & $6.833^{\mathrm{bc}}$ & $17.206^{\mathrm{c}}$ & $4.103^{\mathrm{c}}$ & 2.108 \\
T5 & $0.163^{\mathrm{ab}}$ & $23.43^{\mathrm{ab}}$ & $7.690^{\mathrm{a}}$ & $18.657^{\mathrm{ab}}$ & $4.570^{\mathrm{ab}}$ & 2.129 \\
T6 & $0.182^{\mathrm{a}}$ & $25.69^{\mathrm{a}}$ & $7.642^{\mathrm{ab}}$ & $18.936^{\mathrm{ab}}$ & $4.563^{\mathrm{a}}$ & 2.178 \\
T7 & $0.154^{\mathrm{b}}$ & $23.96^{\mathrm{ab}}$ & $6.499^{\mathrm{c}}$ & $16.769^{\mathrm{c}}$ & $3.957^{\mathrm{c}}$ & 2.010 \\
T8 & $0.168^{\mathrm{ab}}$ & $22.72^{\mathrm{bc}}$ & $7.761^{\mathrm{a}}$ & $19.448^{\mathrm{a}}$ & $4.594^{\mathrm{a}}$ & 2.429 \\
LSD $(0.05)$ & $* *$ & $* *$ & $*$ & $* *$ & $* *$ & 3.42 \\
CV & 10.20 & 6.46 & 6.61 & 4.42 & $\mathrm{NS}$ & 6.95 \\
\hline
\end{tabular}

Values sharing similar letters in a column do not differ significantly at $P<0.05$, according to Fisher's LSD test

$L S D$ least significant difference, $C V$ coefficient of variation, $N S$ non-significant

* and ** significant at $P \leq 0.05$ and $P \leq 0.01$, respectively

Similarly, the highest available residual soil $\mathrm{P}$ was recorded for treatment comprising $75 \%$ RDF plus 11.25 ton $\mathrm{ha}^{-1}$ vermicompost (T6) followed by T4 and T3 (Table 8 ). These treatments were in statistical parity with each other. T6 had a $30.34 \%$ higher P than the control plot, which has scored the lowest value. The increased availability of $\mathrm{P}$ in plots receiving integrated nutrition may be attributed to the fact that vermicompost in combination with mineral fertilizer might have helped the solubilization of precipitated $\mathrm{P}$ to soluble form making it easily available to the plant. As Azarmi et al. (2008) reported, in response to the added vermicompost the solubilization of $\mathrm{P}$ is increased either by microorganism activation with excretion of organic acids or by higher phosphatase activity. The results are in conformity with the findings of Prativa and Bhattarai, (2011) who reported higher available $\mathrm{P}$ content with the integrated use of organic and inorganic fertilizers.

The mean values of the available micro-elements in the soil are also presented in Table 8 . As can be seen from the Table 8, regardless of the chemical fertilizer, the concentration of micronutrients $(\mathrm{Fe}, \mathrm{Mn}, \mathrm{Zn}$ and $\mathrm{Cu})$ in the soil increased with the added rate of vermicompost, however, a statistically significant variation among the treatments was observed only for the three nutrients: $\mathrm{Fe}(P \leq 0.05), \mathrm{Mn}$ and $\mathrm{Zn}(P \leq 0.01)$ (Table 8). The highest and lowest concentration of each of these nutrients was recorded for plots treated with 15 ton $\mathrm{ha}^{-1}$ of vermicompost and those which did not receive vermicompost at any rate, respectively. A significant response of the soil to the added vermicompost was realized when the vermicompost was added at a rate of $\geq 7.5$ ton $^{h^{-1}}$ (for $\mathrm{Fe}$ ) and $\geq 11.25$ ton $\mathrm{ha}^{-1}$ for (for $\mathrm{Mn}$ and $\mathrm{Zn}$ ). Several researchers (Azarmi et al. 2008; Abadi et al. 2011; Nada et al. 2011) who reported the significant increase in soil micronutrients after vermicompost application support the finding of the present study.

\section{Conclusion}

The study revealed that the highest values for the various growth, yield and quality attributing parameters were recorded for the treatment combination consisting $75 \%$ of the $\mathrm{RDF}+11.25$ ton $\mathrm{ha}^{-1}$ vermicompost (T6). This treatment was also observed to have the highest net benefit with acceptable economic return and the highest concentration of post-harvest total $\mathrm{N}$ and available soil $\mathrm{P}$ with fair levels of other macro- and micro-nutrients. The present investigation, therefore, led to the determination of this treatment (T6) as the best treatment combination for optimum fruit yield and quality of tomato. Following this treatment, is the integration of $50 \%$ of RDF +7.5 ton ha ${ }^{-1}$ vermicompost which was observed to surpass the sole mineral fertilizer and vermicompost in terms of the crop's yield and its economic return. Tomato growers may also consider this treatment combination, if in case they could not afford to use the former treatment. Overall, considering yield sustainability, environmental safety, economic viability, soil health improvement and good health of human beings, it may be suggested that vegetable growers of the study area may supplement $25-50 \%$ of the recommended dose of the mineral fertilizer through vermicompost in tomato cultivation. However, it becomes too early to reach a conclusive recommendation from this study; more such studies need to be conducted using more integration ratios of these nutrient sources (NP fertilizer and vermicompost) at various soil and agro-climatic conditions to generate more reliable information. 
It is also worth mentioning that human waste recycling for crop production through vermicomposting technology, being a new scenario in the study area, training and supporting the farming community in issues pertaining to proper collection, handling and composting/vermicomposting of the wastes and their integrated application with mineral fertilizer is of paramount importance. To avoid the health and environmental risks associated with excreta use and to promote its safe and sustainable use in agriculture; appropriate policies, legislation and institutional frameworks that takes the socio-cultural aspect of the community into account need to be designed by the concerned local authorities.

Acknowledgements The authors would like to acknowledge the Ministry of Education of the Federal Democratic Republic of Ethiopia, for its financial support of the present study. They also wish to thank Haramaya University for its cooperation in providing the experimental field and laboratory facilities that were indispensable for the successful completion of the study.

Authors' contributions TM conceived and carried out the study; performed the analyses and drafted the manuscript. HG participated in the design and coordination of the study; KK, KW, BS and HY participated in the design of the study supervised the analysis process and helped draft the manuscript. All authors read and approved the final manuscript.

Competing interests The authors declare that they have no competing interests.

Open Access This article is distributed under the terms of the Creative Commons Attribution 4.0 International License (http://crea tivecommons.org/licenses/by/4.0/), which permits unrestricted use, distribution, and reproduction in any medium, provided you give appropriate credit to the original author(s) and the source, provide a link to the Creative Commons license, and indicate if changes were made.

\section{References}

Abadi ZA, Sepanlou MG, Bahmanyar MA (2011) The effect of municipal compost application on the amount of micro elements and their absorption in soil and medicinal plant of mint (Menthas). Afr J Biotechnol 10(77):17716-17725. doi:10.5897/ AJB10.2462

Agyekum EO (2015) Knowledge, perception and willingness to pay for faecal waste reuse in agriculture by farmers in the NingoPrampram and Shai-Osudoku districts of Ghana. Thesis, Kwame Nkrumah University of Science and Technology, Accra, Ghana

Akhtar M, Naeem A, Akhter J, Bokhari SA, Ishaque W (2011) Improvement in nutrient uptake and yield of wheat by combined use of urea and compost. Soil Sci Soc Pak Soil Environ 30(1):45-49. www.se.org.pk. Accessed 26 May 2015

Arancon NQ, Edwards CA, Bierman P, Metzger JD, Lucht C (2005) Effects of vermicompost produced from cattle manure, food waste and paper waste on the growth and yield of peppers in the field. Pedobiologia 49:297-306. doi:10.1016/j.pedobi.2005.02. 001

Atiyeh RM, Edwards CA, Subler S, Metzger JD (2001) Pig manure vermicompost as a component of a horticultural bedding plant medium: effects on physicochemical properties and plant growth. Bioresour Technol 78:11-20. doi:10.1016/S09608524(00)00172-3

Azarmi R, Giglou MT, Taleshmikail RD (2008) Influence of vermicompost on soil chemical and physical properties in tomato (Lycopersicum esculentum) field. Afr $\mathrm{J}$ Biotechnol 7(14):2397-2401. http://www.academicjournals.org/AJB. Accessed 16 Aug 2015

Chatterjee R (2013) Physiological attributes of tomato (Lycopersicon esculentum Mill.) influenced by different sources of nutrients at foothill of eastern Himalayan region. J Appl Natural Sci 5(2):282-287.www.ansfoundation.org. Accessed 09 Dec 2015

Chatterjee R, Jana JC, Paul PK (2013) Vermicompost substitution influences shelf life and fruit quality of tomato (Lycopersicon esculentum Mill.). Am J Agric Sci Technol 1:69-76. doi:10. 7726/ajast.2013.1006

Chatterjee R, Bandyopadhyay S, Jana JC (2014) Impact of organic amendments and inorganic fertilizers on production potential, nitrogen use efficiency and nitrogen balance in tomato (Lycopersicon esculentum Mill.). IJSK 2(5):233-240. doi:10.12983/ ijsrk-2014-p0233-0240

CIMMYT (International Maize and Wheat Improvement Center) (1988) From agronomic data to farmer recommendations: an economics training manual. Completely Revised Edition, Mexico, DF

Cofie O, Adamtey N (2009) Nutrient recovery from human excreta for urban and peri urban agriculture. Paper contributed to the SuSanA Food Security Working Group Meeting during the WEDC International Conference held in Addis Ababa, Ethiopia, 15 April 2009. http://publications.iwmi.org/pdf/H042722.pdf. Accessed 18 Oct 2015

Das R, Mandal AR, Priya A, Das SP, Kabiraj J (2015) Evaluation of integrated nutrient management on the performance of bottle gourd (Lagenaria siceraria (Molina Standl)). J Appl Nat Sci 7(1):18-25.www.ansfoundation.org. Accessed 19 March 2016

Dass A, Lenka NK, Sudhishri S, Patnaik US (2008) Influence of integrated nutrient management on production, economics and soil properties in tomato under on farm condition in eastern Ghat of Orissa. Indian J Agric Sci 78(1):40-43.http://epubs.icar.org. in/ejournal/index.php/IJAgS/article/view/9764. Accessed 28 Nov 2015

Day PR (1965) Hydrometer method of particle size analysis. In: Black CA (ed) Methods of soil analysis. Am Soc Argon, Madison, pp 562-563

Dick WA, Gregorich EG (2004) Developing and maintaining soil organic matter levels. In: Schjonning P, Elmbalt S, Christensen BT (eds) Managing soil quality: challenging modern agriculture. CAB International, Wallingford, pp 103-120

Domínguez J (2004) State of the art and new perspectives on vermicomposting research. In: Edwards CA (ed) Earthworm ecology. CRC Press, Boca Raton, pp 401-424

Edossa E, Nigussie D, Tena A, Yibekal A, Lemma D (2014) Response of fruit quality of tomato grown under varying inorganic $\mathrm{N}$ and $\mathrm{P}$ fertilizer rates under furrow irrigated and rainfed production conditions. IJDS 2(3): 371-387.www.isdsnet. com/ijds. Accessed 22 July 2015

Edwards CA, Arancon NQ (2004) Interactions among organic matter, earthworms and microorganisms in promoting plant growth. In: Edwards CA, Magdoff F, Weil R (eds) Functions and management of soil organic matter in agroecosystems. CRC Press, Boca Raton, pp 327-376

Ethiopian Agricultural Research Organization (EARO) (2004) Directory of released crop varieties and their recommended cultural practices. Addis Ababa, Ethiopia

Fernández-Luqueño F, Reyes-Varela V, Martínez-Suárez C, Salomón-Hernández G, Yáñez-Meneses J, Ceballos-Ramírez JM, 
Dendooven L (2010) Effect of different nitrogen sources on plant characteristics and yield of common bean (Phaseolus vulgaris L.). Bioresour Technol 1:396-403. doi:10.1016/j.biortech.2009. 07.058

Ferreras L, Gomez E, Toresani S, Firpo I, Rotondo R (2006) Effect of organic amendments on some physical, chemical and biological properties in a horticultural soil. Bioresour Technol 97:635-640. doi:10.1016/j.biortech.2005.03.018

Garner D, Crisosto CH, Wiley P, Crisosto GM (2008)Measurement of $\mathrm{pH}$ and titratable acidity. Cooperative Extension University of California. Cent Val Postharvest Newsl 17(2):1-11.www.uckac. edu/postharv. Accessed 02 July 2014

Giraddi RS (2000) Influence of vermicomposting methods and seasons on the bio-degradation of organic wastes. Indian J Agric Sci 70:663-666.www.cabdirect.org/abstracts/20003034704. html. Accessed 22 Dec 2015

Gopinath KA, Supradip S, Mina BL, Pande H, Kundu S, Gupta HS (2008) Influence of organic amendments on growth, yield and quality of wheat and on soil properties during transition to organic production. Nutr Cycl Agroecos 82(1):51-60. doi:10. 1007/s10705-008-9168-0

International Food Policy Research Institute (IFPRI) (2010) Fertilizer and soil fertility potential in Ethiopia: constraints and opportunities for enhancing the system. Working paper. IFPRI, Washington DC, USA

Javaria S, Khan MQ (2011) Impact of integrated nutrient management on tomato yield, quality and soil environment. J Plant Nutr 34(1):140-149. doi:10.1080/01904167.2011.531605

Koushal S, Sharma AK, Singh A (2011) Yield performance, economics and soil fertility through direct and residual effects of organic and inorganic sources of nitrogen as substitute to chemical fertilizer in rice-wheat cropping system. Res J Agric Sci 43(3):189-193

Lindsay WL, Norvell WA (1978) Development of a DTPA soil test for zinc, iron, manganese and copper. Soil Sci Soc Am J 142:421-428

McLean EO (1982) Soil pH and lime requirement. In: Page AL, Miller RH, Keeney DR (eds) Methods of soil analysis, part 2. Amer. Soc. Agron, Madison, pp 199-224

Motsara RM, Roy RN (2008) Guide to laboratory establishment for plant nutrient analysis. FAO fertilizer and plant nutrition bulletin 19. Food and Agriculture Organization (FAO), Rome

Mupondi LT, Mnkeni PN, Muchaonyerwa P (2010) Effectiveness of combined thermophilic composting and vermicomposting on biodegradation and sanitization of mixtures of dairy manure and waste paper. Afr J Biotechnol 9(30):4754-4763.http://www. academicjournals.org/AJB. Accessed 18 Oct 2014

Murmu K, Swain DK, Ghosh BC (2013) Comparative assessment of conventional and organic nutrient management on crop growth and yield and soil fertility in tomato-sweet corn production system. Aust J Crop Sci 7(11):1617-1626. http://search.informit. com.au/documentSummary; $\mathrm{dn}=644666095606079 ;$ res=IELHSS. Accessed 12 Oct 2014

Nada WM, Rensburg LV, Claassens S, Blumenstein O (2011) Effect of vermicompost on soil and plant properties of coal spoil in the Lusatian region (Eastern Germany). Commun Soil Sci Plant Anal 42:1945-1957. doi:10.1080/00103624.2011.591469

Namazi E, Lack S, Nejad EF (2015) Effect of vermicompost and chemical nitrogen fertilizer application on the various functioning of maize seeds. J Exp Biol Agric Sci 3(3):261-268. doi:10. 18006/2015.3(3).261.268

Nath G, Singh K (2011) Combination of vermicomposts and biopesticides against nematode (Pratylenchus sp.) and their effect on growth and yield of tomato (Lycopersicon esculentum). IIOABJ 2(5):27-35
Ndegwa PM, Thompson SA (2001) Integrating composting and vermicomposting in the treatment and bioconversion of solids. Bioresour Technol 76:107-112. doi:10.1016/S09608524(00)00104-8

Nikbakht A, Kafi M, Babalar M, Xia YP, Luo A, Etemadi N (2008) Effect of humic acid on plant growth, nutrition uptake and postharvest life of Gerbera. J Plant Nutr 31:2155-2167. doi:10. 1080/01904160802462819

Nunes MCN, Emond JP (1999) Chlorinated water treatments affects postharvest quality of green bell peppers. J Food Qual 22:353-361. doi:10.1111/j.1745-4557.1999.tb00563.x

Okalebo JR, Guthua KW, Woomer PJ (2002) Laboratory methods of soil and plant analysis-a working manual. TSBF-CIAT and SACRED Africa, Nairobi

OlivaLlaven MA, Guzman Jimenez JL, Cabrera Coro BI, RinćonRosales R, Montes Molina J, Dendooven L, Gutìerrez-Miceli FA (2008) Fruit characteristics of bell pepper cultivated in sheep manure vermicompost substituted soil. J Plant Nutr 31:1585-1598. doi:10.1080/01904160802244738

Olsen SR, Cole CV, Watanable FS, Dean LA (1954) Estimation of available phosphorus in soil by extraction with sodium bicarbonate. United States Department of Agriculture Circular 939, USDA, Washington DC

Prativa KC, Bhattarai BP (2011) Effect of integrated nutrient management on the growth, yield and soil nutrient status in tomato. Nepal J Sci Technol 12:23-28. doi:10.3126/njst.v12i0.6474

Reddy UR, Reddy SM (2011) Availability of major nutrients in soil as influenced by integrated nutrient management in tomato-onion cropping system. Indian J Hortic 68(2):224-228

Rhoades JD (1982) Soluble salts. In: Page AL (ed) Methods of soil analysis, part 2. Chemical and microbiological properties. Soil Science Society of America (SSSA) Book Series No: 9, Madison, pp 149-157

Sahlemedhin S, Taye B (2000) Procedures for soil and plant analysis. National Soil Research Ceter, Ethiopian Agricultural Research Organization, Addis Ababa

Saraswathy N, Prabhakaran J (2014) Efficacy of vermicompost from vegetable market wastes on yield responses of tomato (Lycopersicon esculentum Mill.). Int J Curr Biotechnol 2(5):12-15. http://ijcb.mainspringer.com. Accessed 08 June 2015

Singh R, Sharma RR, Kumar S, Gupta RK, Patil RT (2008) Vermicompost substitution influences growth, physiological disorders, fruit yield and quality of strawberry (Fragaria $x$ ananassa Duch.). Bioresour Technol 99:8507-8511. doi:10. 1016/j.biortech.2008.03.034

Singh BK, Pathak KA, Boopathi T, Deka BC (2010) Vermicompost and NPK fertilizer effects on morpho-physiological traits of plants, yield and quality of tomato fruits (Solanum lycopersicum L.). Veg Crops Res Bull 73:77-86. doi:10.2478/v10032-010-0020-0

Smith CJ, Bond WJ, Wang W (1999) Waste-free: 'Vermicompost' to improve agricultural soils. CSIRO Land and Water Technical report 23/99. Canberra. CSIRO Land and Water. http://www. clw.csiro.au/publications/technical99/tr23-99.pdf. Accessed 10 April 2013

Srinivasan R (ed) (2010) Safer Tomato Production Techniques: a field guide for soil fertility and pest management. AVRDC-The world vegetable center, Shanhua, Taiwan, p 97

Srivastava PK, Gupta M, Upadhyay RK, Sharma S, Shikha Singh N, Tewari SK, Singh B (2012) Effects of combined application of vermicompost and mineral fertilizer on the growth of Allium cepa L. and soil fertility. J Plant Nutr Soil Sci 175:101-107. doi:10.1002/jpln.201000390

Suge JK, Omunyin ME, Omami EN (2011) Effect of organic and inorganic sources of fertilizer on growth, yield and fruit quality of eggplant (Solanum melongena L). Arch Appl Sci Res. 
3(6):470-479. http://scholarsresearchlibrary.com/archive.html. Accessed 22 May 2015

Sun B, Zhang L, Yang L, Zhang F, Norse D, Zhu Z (2012) Agricultural non-point source pollution in china: causes and mitigation measures. Ambio 41(4):370-379. doi:10.1007/ s13280-012-0249-6

Sundararasu K, Neelanarayanan P (2012) Effect of vermicompost and inorganic fertilizer on the growth and yield of tomato, Lycorpersicon esculentum L. Int J Curr Res 4(7):49-50. http://www. journalcra.com. Accessed 18 Oct 2014

Suthar S (2009) Earthworm communities a bioindicator of arable land management practices: a case study in semi arid region of India. Ecol Indic 9(3):588-594. doi:10.1016/j.ecolind.2008.08.002

Sutton MA, Howard CM, Erisman JW, Billen J, Bleeker A, Grennfelt P, van Grinsven H, Grizzetti B (2011) The European nitrogen assessment, sources, effects and policy perspectives. Cambridge University Press, Cambridge. doi:10.1002/met.1290

Toor RK, Geoffrey PS, Anuschka H (2006) Influence of different types of fertilisers on the major antioxidant components of tomatoes. J Food Compos Anal 19:20-27. doi:10.1016/j.jfca. 2005.03.003
Uz I, Tavali IE (2014) Short-term effect of vermicompost application on biological properties of an alkaline soil with high lime content from Mediterranean region of Turkey. World J, The Sci. doi:10. $1155 / 2014 / 395282$

Van Reeuwijk LP (2002) Procedures for soil analysis, 6th ed. International soil reference and information centre. Technical paper 9. Food and Agriculture Organization of the United Nations (FAO), Wageningen, the Netherlands

Walkley AJ, Black IA (1934) Estimation of soil organic carbon by the chromic acid titration method. Soil Sci 37:29-38

Waskar DP, Khedlar RM, Garande VK (1999) Effect of postharvest treatment on shelf life and quality of pomegranate in evaporative cooling chamber and ambient conditions. J Food Sci Technol 2(36):114-117. www.cat.inist.fr/?aModele=afficheN\&cpsidt $=$ 1908499

Yourtchi MS, Hadi MH, Darzi MT (2013) Effect of nitrogen fertilizer and vermicompost on vegetative growth, yield and NPK uptake by tuber of potato (Agria CV). Int $\mathrm{J}$ Agric Crop Sci 5(18):2033-2040. http://ijagcs.com/wp-content/uploads/2013/ 08/2033. Accessed 17 April 2014 